tillation of the key events, it is those details that give the book its appeal. I found I wanted to read just one more paragraph each time before I put the book down. I was surprised when I realized I was over half way through the book and it seemed I had just started. As I stated initially this is really a history text, but it covers a key era in the story of Canada. The only important

\section{Eighteenth-century Naturalists of Hudson Bay}

By Stuart Houston, Tim Ball and Mary Houston. 2003. McGill-Queen's University Press, 3430 McTavish Street, Montreal, Quebec, H3A 1X9. xxiv + 333 pages 49.95 CAD Cloth.

In 1959, C. Stuart Houston and Maurice G. Street began to introduce prairie naturalists to the pioneering contributions of employees and other associates of the Hudson's Bay Company and to expand our understanding of the natural history of Canada's Arctic and prairie regions (Houston and Street 1959) in the first of a long series of articles, books, notes and papers by Houston and numerous colleagues on biographies of specific contributors and the history of various aspects of these contributions. In this volume, Stuart and his chief collaborator (Mary I. Houston) bring many of the details of their earlier publications together, expand on the European collaborators of these naturalists and compare the Hudson's Bay contributions with approximately contemporary efforts in South Carolina. They also collaborate with Timothy E. Ball in outlining the contributions of H.B.C. officials in documenting climatological details at various sites and their changes over a long time period and with Arok Wolvengrey and Jean Okimasis in documenting Cree names for numerous natural history species in the lands of the vast territory formerly controlled by H.B.C.

The book opens with a series of introductory sections, including a list of McGill-Queen's "Native and Northern Series" (of which this is the $34^{\text {th }}$ ), a dedication to William B. Ewart (whose efforts led to the moving of the extensive Hudson's Bay Company archives from England to Winnipeg), lists of contents, illustrations and tables, eight colour plates of birds originally published in two of four 1743-1751 volumes by George Edwards, acknowledgments, a list of supplementary documents available through the internet, a list of abbreviations and a foreword by the Keeper of the Hudson's Bay Archives, Judith Hudson Beattie. The main text of the book (pages 1-142) consists of an unnumbered introductory chapter, followed by 12 numbered chapters. Seven appendices occupy almost as many pages (pages 143-251). About 40 pages of footnotes, 25 pages of references and a 14-page index close the book.

The main text starts with a short outline of the history of Hudson's Bay Company activities in North America and the role of HBC officials in documening natural history features of much of the prairie prov- note of natural history concerns the surgeon, Edward Adams, for whom the Yellow-billed Loon was named Gavia adamsii. It is well worth the read if you love the Arctic, enjoy history or are a Franklin buff.

ROY JOHN

2193 Emard Crescent Ottawa, Ontario K1J 6K5 Canada

inces, Ontario, Quebec, Nunavut and adjacent areas in collaboration with native North Americans and European scientists. The first numbered chapter consists of brief biographies of seven European scientists who received and/or examined animal specimens collected by HBC personnel, described and often named them, and wrote the first accounts of their behaviour and other natural history features. The role of these specimens in developing Linnaeus's system of classification of plants and animals is outlined. Eight chapters follow on the contributions and efforts by eight specific HBC officials (Peter Fidler, Andrew Graham, Samuel Hearne, Thomas Hutchins, James Isham, Alexander Light, Humphrey Marten and Moses Norton). The tenth numbered chapter summarizes these contributions, lists Hudson Bay area bird species mentioned in ten early manuscripts, provides several background details and notes several corrections and omissions in earlier publications. The eleventh chapter, based primarily on four years of archival research by Ball, outlines weather, climate and climatic changes in the area, as documented through records of 30 or more years at $30 \mathrm{HBC}$ posts. The final chapter outlines early contributions to North American natural history by early settlers of Charles Town, South Carolina, when that area was still a British colony. Brief biographies of two contributors of meteorological data and two natural history collectors are included, as well as a list of species named as new in Mark Catesby's 1729-1747 two-volume treatise on the birds of South Carolina (58 from "South Carolina," seven from other parts of eastern U.S. states, seven from the Caribbean, and one from "Quebec."

Seven appendices cover about 100 pages. The longest (about 50 pages) by the Houstons, Jean Okimasis and Arok Wolvengrey lists words used in the eighteenth century in four Cree dialects for various taxa that live in the territory controlled by the Hudson's Bay Company. Another lists departure and arrival dates and the captains of ships sailing between York Factory and Europe from 1716 to 1892.

Smiles will cross the faces of Saskatchewan naturalists, long aware that two of their most prominent members (Margaret Belcher and Mary Houston) were sisters, when they read that one of two ships captained by a Belcher (twice) was "Mary." A two-page appendix by Deirdre Simmons outlines the history of the Hudson's Bay Company Archives. Others concern ten man- 
uscripts that have variously been attributed to Andrew Graham and Thomas Hutchins, and plagiarism of Graham by Hutchins. The Houstons provide an interesting account of their research in the archives, in London and at a symposium in the Orkney Islands that brought them to the conclusion that these manuscripts resulted from collaboration. Other appendices concern the tenyear cycles of various northern birds and mammals, the effects of nineteenth century trade on Trumpeter Swans, and the naming of Canada Goose prior to the official existence of Canada. I assumed that the latter was a combined reprint of two earlier publications in Blue Jay (Houston 1994, 1995), but some of it presents additional findings of historical research that was stimulated by the earlier notes.

Naturalists interested in historical aspects of nature study will find plenty of interest in this volume. It is written well and researched thoroughly. I found no substantial errors, although a few references cited were either not included in the literature lists or the publication dates and/or author list in the text differed slightly from those in the literature list. One reference (Ross 1834 ) is listed in a footnote (page 256), but not in the references. Three references cited are not included in the literature list (Gmelin [1788 on page 140], McIntyre and Houston [1999] on page 269) and Rousseau [1969] on page 279, although enough information on the latter is included to enable a reader to track it down). The 1983 book by Peck and James should be listed as Volume 1. Footnote 39 on page 255 on William Wales should refer to Chapter 11, not 12 . References to Appendix E and Figure 3.13 on page 52 apply to Appendix F and Figure 3.14; respectively.
The abbreviated forms of the authors' names from the more usual versions that they use in publications (Timothy E. Ball, C. Stuart Houston and Mary I. Houston) provides potential confusion for bibliographers who may think that other, presumably related, authors are involved, especially as their usual publication versions are used in some appendices. As noted by Meyer (2004), some of the appendices would be more appropriate within the main text. Although the literature list is substantial, readers new to the subject who wished to follow up with further reading would have benefited from inclusion of more of Houston's previous biographies, book chapters, notes and papers on some of the subjects covered. Similarly, although biographical references are included for many people, none are included for a few (for example, William Rowan) for whom several are available. None of these criticisms detract substantially from the overall high quality of this excellent contribution to the history of nature study in North America.

\section{Literature Cited}

Houston, C. S. 1994. How did the Canada Goose get its name before there was a Canada? Blue Jay 52: 141-143.

Houston, C. S. 1995. Earlier use of the name Canada Goose. Blue Jay 53: 116-117.

Houston, C. S. and M. G. Street. 1959. The birds of the Saskatchewan River Carlton to Cumberland. Saskatchewan Natural History Society Special Publication Number 2, Regina.

Meyer, D. 2004. [Review of] Eighteenth-century naturalists of Hudson Bay. Blue Jay 62: 120-122.

MARTIN K. MC NICHOLL

Apartment 105, 8752 Centaurus Circle, Burnaby, British Columbia V3J 7E7 Canada

\section{Hunters at the Margin: Native People and Wildlife Conservation in the Northwest Territories}

By John Sandlos. UBC Press, 2029 West Mall, Vancouver, British Columbia V6T 1Z2. 360 pages, 85.00 CAD Cloth, 39.95 CAD Paper

Professor Sandlos has written a very well-researched text on three major conservation issues. He examines the plight of the Bison, Muskox and Caribou in Canada's north. The author has examined the questions raised about hunting of these three key species and the development and enforcement of laws relating to them. He has done this with a very sympathetic attitude towards Canada's original inhabitants. He compares the lifestyle and requirements of aboriginals to the efforts of Ottawa's bureaucrats to control hunting and to conserve these mammals. These two philosophies are rarely compatible, and this leads to conflict.

I had a hard time reading this book. While I understand the author's sympathy with Canada's aboriginal people I found his constant innuendo very galling. When discussing the native viewpoint he writes without emphasis. When writing about the non-native people's actions he frequently uses parentheses, causing the reader to doubt the adjective's veracity. When defending the native people Sandlos ignores much pertinent information. He proposes the natives are not the wanton killers portrayed by white policemen, wardens and travelers, but long before the arrival of the white man the natives hunted Mammoths, Giant Sloths and others to extinction. This was also before climate change pushed these creatures over the edge [as in Europe]. The latest book on Caribou (Bergerud et al. 2007) notes that after an influenza epidemic decimated native populations, Caribou increased [see review this issue]. In my own experience, two years ago at Cambridge Bay, I was informed the hunting ban on Muskox had been lifted a few months earlier and the town's residents had shot the entire local herd. I had to travel out of town for an hour by truck and an hour and a half on foot to see distant Muskox on this island.

Before the arrival of whites, there were few natives in the north; it was too hostile a climate. Living was easier on the plains with its abundant Bison. In fact the author provides evidence for this concept when he quotes a convicted poacher, Joseph Wakwan, as preferring to hunt the larger Bison over the legal Moose. 